$11-1-2009$

\title{
Becoming The Boss: Discretion And Postsuccession Success In Family Firms
}

J. R. Mitchell

Western University, rmitchell@ivey.uwo.ca

Timothy A. Hart

Oklahoma State University, tim.hart@okstate.edu

\section{Sorin Valcea}

Cleveland State University, s.valcea@csuohio.edu

David M. Townsend

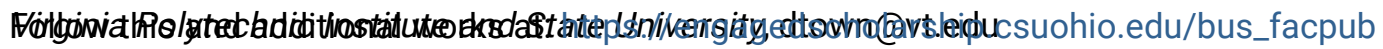

Part of the Business Administration, Management, and Operations Commons, and the Entrepreneurial and Small Business Operations Commons

How does access to this work benefit you? Let us know!

\section{Publisher's Statement}

This is the accepted version of the following article: Mitchell, J.R., Hart, T.A., Valcea, S., \& Townsend, D.M. (2009). Becoming the boss: Discretion and postsuccesson success in family firms. Entrepreneuership Theory and Practice, 33(6), 1201-1218. doi: 10.1111/ j.1540-6520.2009.00341.x, which has been published in final form at http://onlinelibrary.wiley.com/doi/10.1111/j.1540-6520.2009.00341.x/abstract

\section{Original Published Citation}

Mitchell, J.R., Hart, T.A., Valcea, S., \& Townsend, D.M. (2009). Becoming the boss: Discretion and postsuccesson success in family firms. Entrepreneuership Theory and Practice, 33(6), 1201-1218. doi: 10.1111/j.1540-6520.2009.00341.x

This Article is brought to you for free and open access by the Monte Ahuja College of Business at EngagedScholarship@CSU. It has been accepted for inclusion in Business Faculty Publications by an authorized administrator of EngagedScholarship@CSU. For more information, please contact library.es@csuohio.edu. 


\title{
Becoming the Boss: Discretion and
}

\section{Postsuccession Success}

\section{in Family Firms}

\author{
J. Robert Mitchell
}

Timothy A. Hart

Sorin Valcea

David M. Townsend

Family firms can enjoy substantial longevity. Ironically, however, they are often imperiled by the very process that is essential to this longevity. Using the concept of managerial discretion as a starting point, we use a human agency lens to introduce the construct of successor discretion as a factor that affects the family business succession process. While important in general, successor discretion is positioned as a particularly relevant factor for productively managing organizational renewal in family businesses. This study represents a foundation for future empirical research investigating the role of agency in entrepreneurial action in the family business context, which consequently can contribute to the larger research literature on succession and change.

Shirtsleeves to shirtsleeves in three generations.-Fukuyama, 1995

$\mathbf{F}$ rom the standpoint of firm survival, three generations represent a considerable degree of persistence. Indeed, family firms, on average, survive longer than nonfamily firms (e.g., Górriz \& Salas, 2006). But the near universality of the above proverb (Harriss, 2003; Schumann, 1999; Wong, 1985) nonetheless indicates that variability in how control of family firms is transferred to the leaders in the next generation can systematically (and potentially detrimentally) impact the viability of these firms across generations (Miller, Steier, \& Le Breton-Miller, 2003). Herein exists a tension: The considerable longevity that family firms sometimes enjoy is imperiled by the very processes that are necessary for their continued existence. On the one hand, family firms can have considerable stability as a result of intergenerational ties (Sirmon \& Hitt, 2003); but on the other hand, these firms can have "problems of passage" that reflect "an inappropriate relationship between past and future" (Miller et al., p. 528). It is these problems of passage to the future that we seek to investigate. 
Building on previous family firm succession research (e.g., Davis \& Harveston, 1998; Matthews, Moore, \& Fialko, 1999; Miller et al., 2003; Sharma, Chrisman, Pablo, \& Chua, 2001; Shepherd \& Zacharakis, 2000), we seek to understand the factors that influence postsuccession success by focusing on the postsuccession agency of successors. As a foundation for this investigation, we first develop the idea of postsuccession managerial discretion of successors (cf. Hambrick \& Finkelstein, 1987) by introducing the notion of successor discretion to capture the human agency aspect of managerial discretion in succession (Bandura, 2001). This then permits us to investigate the moderating effect of family business on the factors that are thought to affect successor discretion. Our argument is that because of individual-level differences, some successors are not as free to take the risks necessary to maintain the family firm's entrepreneurial edge and maximize a family's wealth, and that this lack of agency can be exacerbated by family firm-level factors. In this way, our research contributes not only to the family business literature in its focus on postsuccession success in family firms, but also to the broader literature on discretion and succession, where the family business represents a uniquely positioned microcosm for understanding a broader phenomenon.

Our paper is organized as follows. First, we develop the construct of successor discretion to extend the construct of managerial discretion using an agency lens and discuss its importance in both nonfamily and family firms. Second, we review the expectations of managerial discretion research as it relates to successor discretion and investigate the impact of the family business on these relationships. Finally, we discuss the theoretical and practical implications of our model vis-à-vis the question of why some firms (especially family firms) are able to successfully manage succession while others are not, offering several suggestions for future research.

\section{Agency, Successor Discretion, and Postsuccession Success}

\section{Agency and Successor Discretion}

Our work draws upon previous research that has addressed intergenerational succession in family firms and the factors and processes that affect the long-term survival of such firms (e.g., Le Breton-Miller, Miller, \& Steier, 2004; Matthews et al., 1999; Olson et al., 2003; Sharma, Chrisman, \& Chua, 2003; Shepherd \& Zacharakis, 2000). Succession in family firms refers to the transfer of managerial control from one generation to the next (Shepherd \& Zacharakis). This process of transferring control is one that is often fraught with challenges (Miller et al., 2003). For instance, prior research indicates that founders who maintain influence after they have largely removed themselves from operational responsibilities (Davis \& Harveston, 1998) can negatively affect successors' job satisfaction and the overall success of succession (Sharma et al., 2001, 2003). Additionally, the entrenchment of previous generations can be problematic because it inhibits the ability of successors to make needed strategic adjustments (Sharma \& Manikutty, 2005). Central to our thesis is the idea that beyond the factors that may inhibit successor control there also exist factors that enable it (e.g., the individual makeup, skills, and abilities of successors). In this way, research into the succession process needs to consider the willingness of incumbents to transfer control, the willingness of successors to take it, as well as successors' subsequent level of commitment to and decision making for the family (Sharma et al., 2001).

We build upon these elements by adopting a human-agency perspective (e.g., Bandura, 2001) of family business postsuccession success that is situated in, and extends, the concept of managerial discretion. Managerial discretion has been defined to be "latitude of action" 
(Hambrick \& Finkelstein, 1987, p. 371) and "is a function of (1) the degree to which the environment allows variety and change; (2) the degree to which the organization itself is amenable to an array of possible actions and empowers the chief executive to formulate and execute those actions; and (3) the degree to which the chief executive personally is able to envision or create multiple courses of action" (Hambrick \& Finkelstein, p. 379, emphasis added). While the task environment and the organization are both central to managerial discretion (representing the bulk of the research), our agency-based approach to postsuccession success - wherein agency is described as the ability "to intentionally make things happen by one's actions" (Bandura, p. 2) — centers on this third (individual) dimension: the ability to envision and create future courses of action.

While research on managerial discretion received significant attention following its introduction, most of this research focused on the environmental and organizational dimensions (e.g., Haleblian \& Finkelstein, 1993; Hambrick \& Abrahamson, 1995; Peteraf $\&$ Reed, 2007). What attention has been given to the individual-centric dimension of managerial discretion has been relatively limited (e.g., Carpenter \& Golden, 1997). Our research represents an attempt to elaborate on this individual-centric dimension of managerial discretion by highlighting the agency of the chief executive successor. Whereas managerial discretion refers to latitude of action, our agency approach expands upon this notion by suggesting that successors' decisions produce important firm-level consequences (Aldrich, 1999). In doing so, we not only bound our study to the chief executive family successor, but also acknowledge that elements of our theorizing can also apply to nonfamily successors in family firms, as well as nonfamily firms.

Central to an agentic approach to postsuccession success are four core features of agency (Bandura, 2001): intentionality (i.e., plans of action), forethought (i.e., expectations of future events), self-reactiveness (i.e., motivation and self-regulation), and selfreflectiveness (i.e., examinations of one's own functioning). The idea is that successful successors are likely to display these features in their actions. And just as these core features of agency enable individuals to engage in "self-development, adaptation, and self-renewal in the face of change" (Bandura, p. 2), so too should they enable successors to develop, adapt, and renew the family firm in the face of change. In our treatment of managerial discretion, we make explicit the notion of human agency by introducing the construct of successor discretion, which elaborates upon Hambrick and Finkelstein's (1987) third (individual) dimension of managerial discretion as described previously: the ability to envision and create future courses of action.

We define successor discretion as the extent to which successors are free and willing to formulate, modify, and enact future plans for the renewal of the company. This conceptualization not only partially encompasses the concept of managerial discretion as outlined previously (e.g., Hambrick \& Finkelstein, 1987) but also extends it by (1) drawing attention to successors' agency as a primary mechanism for envisioning and creating courses of action and (2) highlighting the need for considering future success in discretion. It does so by focusing on the ability of successors to formulate, modify, and enact future-oriented plans of action in the midst of a changing firm environment. Additionally, by establishing successor discretion as a refinement of the larger construct of managerial discretion, we explicitly introduce to discretion research the notion of constraints on choice (Bandura, 2001). Successor discretion, therefore, is not defined solely by a successor's formal role within the firm, but rather, consistent with emerging literature on human agency (Bandura; Searle, 2001), derives from the ability and willingness of successors to shape the firm's strategic direction. And while our expectation is that the factors that lead to successor discretion are generally applicable to all firms, our focal argument is that the impact of these factors on successor discretion will specifically differ in family businesses. 


\section{The Importance of Successor Discretion}

We argue that the efficacy of succession strategies - an important and frequently researched question in both family (e.g., Le Breton-Miller et al., 2004; Sharma et al., 2001; Shepherd and Zacharakis, 2000) and nonfamily firms (e.g., Rubenson \& Gupta, 1996; Virany, Tushman, \& Romanelli, 1992; Wasserman, 2003)—-hinges on the key issue of the establishment of successor discretion on the part of the successor. In general, the success and wealth created by the actions of an entrepreneurial founder can make it easy to keep the strategies of predecessors (family or nonfamily) intact. In these situations, the core capabilities that led to past success for the firm can be inappropriate for the future and can instead result in core rigidities (Leonard-Barton, 1992). Such core rigidities can make it increasingly difficult for successors to take new risks and adapt a business to a changing economic landscape. But such an ability to adjust to change by changing strategies is critical for long-term success (e.g., Smith \& Grimm, 1987) even if risk and change also heighten the possibility of failure. In this way, successor discretion can be said to enable corporate entrepreneurship, which involves the creation of new business within an existing organization and/or the transformation of that organization (Guth \& Ginsberg, 1990, p. 5). And while there is risk involved in corporate entrepreneurship, it also enables the renewal of the organization and can result in improved long-term performance (Zahra \& Covin, 1995).

While important for all firms, corporate entrepreneurship is particularly important for family businesses because of their inherent (and potentially change-independent) longevity. Of course, with a need to be entrepreneurial also comes risk. But undertaking risk in the pursuit of innovative ideas and concepts is important for the family business to remain competitive in a dynamic environment (Ireland, Hitt, \& Sirmon, 2003). And although corporate entrepreneurship is important for family firms, it may not come easily due to concerns about risk and constraints that are imposed as a result of family control (Kellermanns \& Eddleston, 2006). Compounding this issue, particularly in the case of chief executive family successors, is the fact that family firms' choice set for family successors is (naturally) more limited than for nonfamily firms. As such, it is critical for key decision makers in family firms to understand which factors are relevant to successor discretion and which of those factors are within their control. In this way, our study seeks to address the factors that put successors in a position to look beyond the practices established by founders and apply their own creative energy and risk taking to bear for the further advancement of the family firm. In the next section, we summarize the factors that lead to successor discretion in general and then, as our focus, theorize how factors related to a family firm will affect successor discretion specifically.

\section{Successor Discretion and the Family Firm}

We have introduced the construct of successor discretion to elaborate on the individual-centric dimension of managerial discretion. Again, this dimension of discretion focuses on the chief executive successor and the extent to which he or she is able to envision and create future courses of action (Hambrick \& Finkelstein, 1987, p. 379). In our use, successor discretion more explicitly introduces successors' agency as an important element of discretion. Positioned as such, successor discretion is expected to be affected by factors that are similar to those that affect managerial discretion. In the next section, we begin with a summary of the individual-level propositions suggested by Hambrick and Finkelstein (pp. 386-389) that describe a representative set of factors 


\section{Figure 1}

\section{Successor Discretion and the Family Firm}

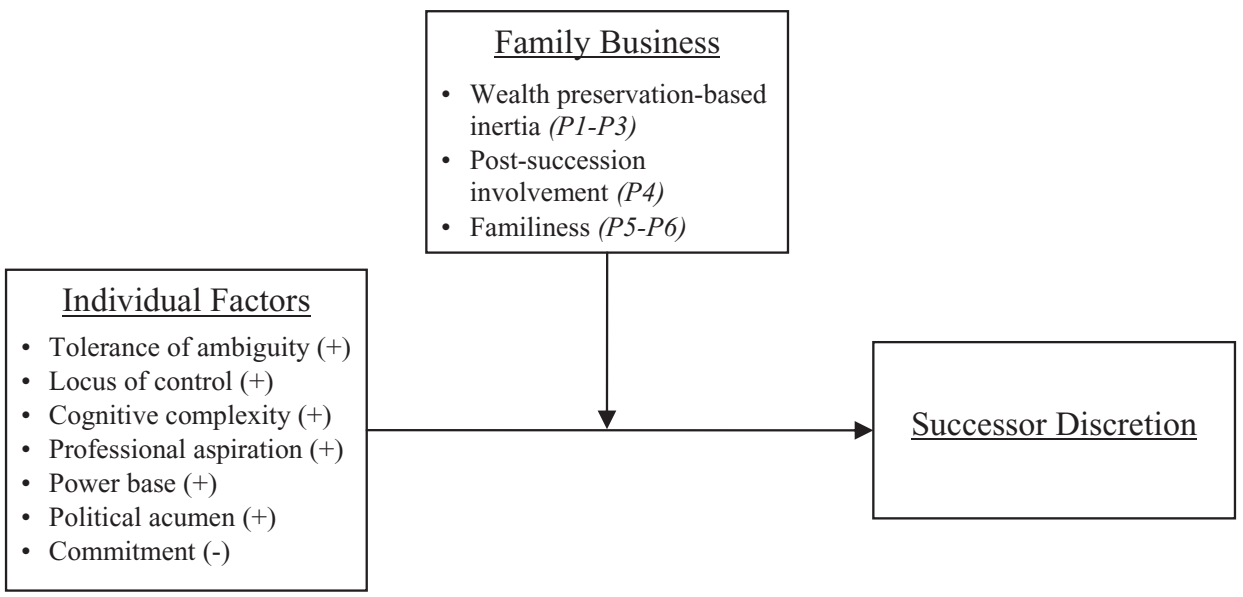

Note: The "+/-" indicate the expected impact on successor discretion.

expected to lead to successor discretion. ${ }^{1}$ Then, in line with our central purpose, we present a set of propositions that examine the effect of family business on successor discretion.

\section{Factors Affecting Successor Discretion}

This section provides a summary of Hambrick and Finkelstein's (1987) work. ${ }^{2}$ They suggest seven factors as being relevant to the individual-centric element of managerial discretion, and thus successor discretion: tolerance of ambiguity, internal locus of control, cognitive complexity, aspiration level, power base, political acumen, and commitment. Because our focus is the discretion of successors, we refer to successor discretion in our treatment of their propositions. The nature of these propositions is depicted in Figure 1.

The first factor affecting successor discretion is successors' tolerance of ambiguity (Furnham \& Ribchester, 1995). The logic here is that those successors who are less tolerant of ambiguity are less likely to contemplate new directions for the firm. Thus, the greater the tolerance of ambiguity, the greater the successor discretion.

The second factor affecting successor discretion is successors' locus of control (Rotter, 1990). Those successors who have a stronger belief that events are beyond their own control are less likely to exhibit control in their own decision making. These successors will have a more limited choice set than those successors who have an internal locus of control. Thus, the more internally focused successors' locus of control, the greater the successor discretion.

The third factor affecting successor discretion is successors' cognitive complexity (Bieri et al., 1966). The expectation is that those successors who are less cognitively

1. While we expect other individual-level factors to also lead to successor discretion, we limit our focus here to those factors suggested by Hambrick and Finkelstein (1987) in an attempt to provide the parsimony necessary for our treatment of the effect of family business on successor discretion.

2. For a more in-depth treatment, please see Hambrick and Finkelstein (1987). 
constrained will have a wider choice set than those who are more cognitively constrained. Accordingly, the greater the complexity of successors' cognitive processing abilities, the greater the successor discretion.

The fourth factor affecting successor discretion is successors' level of professional aspiration. Because greater levels of aspiration are expected to be associated with more and broader search behavior (Cyert \& March, 1963), the greater the level of successors' professional aspiration, the greater the successor discretion.

The fifth factor affecting successor discretion is successors' power base. The greater the successors' power (in terms of ownership, prestige, expertness, etc.) (Finkelstein, 1992), the better enabled they are at considering new (and potentially controversial) directions for the renewal of the firm. In this way, the greater the successors' power base, the greater the successor discretion.

The sixth factor affecting successor discretion is successors' political acumen. The notion is that those successors who are politically astute will be better able to enact new (but again potentially controversial) directions for the firm that could not be considered by less politically astute successors, thus providing a larger choice set to these successors. Accordingly, the greater the successors' political acumen, the greater the successor discretion.

The seventh factor affecting successor discretion is commitment. The idea is that while commitment is necessary, too much of it can lead executives to be locked into specific courses of action (Staw, Sandelands, \& Dutton, 1981), which can constrain future options. In this way, the greater the successors' commitment to a course of action, the less the successor discretion.

\section{The Family Business and Successor Discretion}

While successor discretion is important in all firms, we argue that its importance is singular in family businesses where the family may have a substantial influence on the firm and where successors are embedded in a web of complex familial and social relationships (Mitchell, Morse, \& Sharma, 2003). In addition to the challenges that accompany succession (whether in family or nonfamily firms), there are prominent characteristics of family firms and family firm succession that we argue successors must take into account. Three that are salient to our research include: (1) inertia that exists as a result of a focus on wealth preservation (e.g., Sharma, Chrisman, \& Chua, 1997); (2) postsuccession predecessor involvement (e.g., Sharma et al., 2003); and (3) familiness (e.g., Chua, Chrisman, \& Sharma, 1999).

While these three aspects of family firms can lead to stability and continuity over time, they can also lead to the "problems of passage" that can imperil the future of the firm (Miller et al., 2003, p. 528). By investigating the effect of family business on successor discretion, we seek to better understand how these problems of passage arise. In nonfamily businesses, where the role of the president/CEO is more broadly construed and is generally quite independent of the predecessor (Daily, McDougall, Covin, \& Dalton, 2002), such problems of passage are not nearly as salient. In this way, the family business represents a uniquely positioned microcosm for understanding successor discretion in general. In the next paragraphs we discuss in more depth the nature of these family business characteristics and then develop the logic for their moderating effect on the respective factors that lead to successor discretion as conceptualized.

We begin by examining the impact of wealth preservation-based inertia on the relationships between tolerance of ambiguity, internal locus of control, cognitive complexity, and aspiration level on successor discretion. We then investigate the impact of 
postsuccession predecessor involvement on the relationship between power base and successor discretion. Finally, we consider the impact of familiness on the relationship between political acumen and commitment on successor discretion. In doing so, we acknowledge that while these characteristics of family businesses are conceptually distinct, there is a degree of overlap in their impact on successor discretion.

\section{Wealth Preservation-Based Inertia}

The first characteristic of family firms that we argue should be taken into account in successor discretion-based descriptions of succession is the inertia generated as a result of a focus on wealth preservation. Carney (2005) suggested that family firms are more concerned with the conservation and allocation of resources than nonfamily firms because the family wealth is at stake. For this reason, leaders of a family business may become conservative and unwilling to take entrepreneurial risks (Sharma et al., 1997) to enact key changes within the family firm (Chandler, 1990; Sharma \& Manikutty, 2005). This focus on conserving family wealth creates strong family firm-specific inertial forces in the form of institutionalized "best practices" (e.g., Hannan \& Freeman, 1984), which encourage successors to persist in current strategies and discourage them from taking entrepreneurial risks. We again emphasize that while inertial forces may be present in family and nonfamily firms alike, the unique element of trying to maintain family wealth strengthens inertial forces in family firms. In the next paragraphs, we discuss the impact of wealth preservation-based inertia on the relationships underlying successor discretion.

Family Business, Tolerance of Ambiguity, and Locus of Control. Previously, we described the impact of both tolerance of ambiguity and internal locus of control on successor discretion (cf. Hambrick \& Finkelstein, 1987). Tolerance of ambiguity is defined as the way in which individuals "perceive and process information about ambiguous situations or stimuli when confronted by an array of unfamiliar, complex, or incongruent clues" (Furnham \& Ribchester, 1995, p. 179). Internal locus of control, on the other hand, is defined as the degree to which individuals expect that an outcome is contingent on their own behavior/personal characteristics as opposed to outside forces (Rotter, 1990). While clearly distinct traits, both have in common a dispositional basis in personality, making them prone to stability. This shared element leads to similar expectations for both tolerance of ambiguity and locus of control vis-à-vis the effects of family business, leading us to consider both elements in conjunction.

In their discussion of the impact of locus of control on discretion, Carpenter and Golden (1997) provided a logic underlying the role of personality characteristics in discussions of discretion. They noted that the "personality-situation interactionism" perspective would indicate a differential impact of dispositional traits on behavior based on the nature of the situation (Mischel, 1977; Weiss \& Adler, 1984). The idea is that in strong situations - those in which there is a shared understanding of both the interpretations of issues and appropriate responses to those issues - the impact of dispositional factors is decreased (Carpenter \& Golden, p. 189). As we have described it, a family business situation that affects wealth preservation and leads to inertia is reflective of a strong situation as it is defined in the literature (Mischel; Weiss \& Adler). In this way, preserving wealth denotes an adherence to the accepted practices and accepted rules of the past, which thus serve to constrain the direction of future behavior (Weiss \& Adler, p. 20). In such strong situations, the effects of traits will decrease. Thus,

Proposition 1a: In a family business, wealth preservation-based inertia will attenuate the positive effect of a successor's tolerance of ambiguity on successor discretion. 
Proposition 1b: In a family business, wealth preservation-based inertia will attenuate the positive effect of a successor's internal locus of control on successor discretion.

Family Business and Cognitive Complexity. In contrast to tolerance of ambiguity and locus of control, cognitive complexity is not solely dispositional in nature. Rather, it reflects a combination of dispositional and situational elements (Woike \& Aronoff, 1992). Our theorizing on the subject reflects this relationship. As noted, increases in cognitive complexity are expected to increase successor discretion (cf. Hambrick \& Finkelstein, 1987). According to Bieri et al. (1966), cognitive complexity refers to "the capacity to construe social behavior in a multidimensional way" (p. 185). In relation to successor discretion, successors who exhibit greater complexity in cognitive processing abilities are able to create broader decision sets as a result of their ability to perceive opportunities embedded in dynamic environments (e.g., Baron \& Ensley, 2006). Stated differently, executives with higher levels of cognitive complexity are less likely to accept generic, monolithic interpretations of changes in the environment, but instead understand how to translate these nuanced changes into meaningful opportunities.

But as noted, wealth preservation-based inertial pressures in family firms can limit the range of acceptable practices within the firm. The result of these limitations is the restriction of the opportunity choice set of cognitively complex family business successors (White, Smith, \& Barnett, 1994). When combined with a cognitive context that is already highly complex (Mitchell et al., 2003), the benefits of greater cognitive complexity on the part of successors are diminished. By enforcing family norms governing the appropriateness of behavior in an already complex cognitive environment (Handler, 1992), wealth preservation-based inertial pressures weaken the ability of successors to enact strategic changes in response to the recognition of emerging opportunities. Accordingly,

Proposition 2: In a family business, wealth preservation-based inertia will attenuate the positive effect of a successor's cognitive complexity on successor discretion.

Family Business and Professional Aspiration. As noted, the professional aspirations of successors are expected to increase successor discretion (cf. Hambrick \& Finkelstein, 1987) because individuals with high aspirations are expected to engage in broader search (Cyert \& March, 1963) and thus should have more options available. In family firms, however, the high aspirations of successors may be countered by a tendency to preserve wealth (Carney, 2005), leading to an unwillingness to take entrepreneurial risks (Sharma et al., 1997). Ironically, this tendency might be in spite of higher aspirations, or may even reflect a refocusing of aspirations on wealth preservation. Shepherd and Zacharakis (2000) explain this wealth-preservation behavior through the use of the "endowment effect" concept (e.g., Kahneman, Knetsch, \& Thaler, 1990). The logic is that individuals tend to be motivated to protect that which they own more than they tend to pursue other opportunities of similar value. When considering that executives of family firms typically enjoy longer tenures than those in nonfamily firms (Schulze, Lubatkin, Dino, \& Buchholtz, 2001) and that the endowment effect is likely to increase with time (Strahilevitz \& Loewenstein, 1998), we expect successors in a family firm to focus their aspirations on wealth preservation rather than wealth generation, thereby limiting their focus on future plans for the renewal of the company. Therefore,

Proposition 3: In a family business, wealth preservation-based inertia will attenuate the positive effect of a successor's professional aspirations on successor discretion. 


\section{Postsuccession Predecessor Involvement}

In addition to inertial forces generated as a result of a focus on wealth preservation, the second characteristic of family firms that we argue should be taken into account when considering successor discretion is postsuccession involvement of predecessors. Past research has cited predecessors' reluctance to step aside as one of the most severe problems related to succession in family firms (e.g., Sharma et al., 2001). As such, it represents an important moderator to consider when examining succession in family firms (Sharma et al.). Predecessors typically enjoy a central role in the business they created or developed and are reluctant to give up control (Rubenson \& Gupta, 1996). The ability to exercise influence in both the family and business spheres of the family firm (see, e.g., Holland \& Boulton, 1984) allows executives of family firms to enjoy longer tenures than those in nonfamily firms (Schulze et al., 2001) and to influence decisions even after the succession, regardless of the formal role they retain (Davis \& Harveston, 1998). The continual involvement of predecessors decreases successors' satisfaction with the succession process (Sharma et al., 2003) and increases conflict in the family firm (Davis \& Harveston, 1999). We next discuss how predecessor involvement moderates the relationship between successors' power base and successor discretion.

Family Business and Power Base. The more power successors have, the more successor discretion they will have (cf. Hambrick \& Finkelstein, 1987). However, even after the transition of formal authority from the predecessor to successor, predecessors may retain influential informal power within the firm, undermining the power of the successor (Davis \& Harveston, 1998). While predecessor involvement may be present in both family and nonfamily firms, unique aspects of family firms increase the likelihood of this situation, as well as increasing the magnitude of its negative effects, as previously discussed.

While predecessors may make useful contributions to the family firm after a succession (e.g., as advisors or mentors), such continued involvement poses a potential threat to the successor's power base. In addition to their continued business-related involvement, predecessors in family firms are able to stay involved and influential in ways that predecessors in nonfamily firms cannot (Davis \& Harveston, 1999). Specifically, even after formal business ties are cut and formal power is transferred from the predecessor to successor, family ties typically remain between predecessors and other members of the family in family firms but are rarely present in nonfamily firms. Additionally, there is an expectation that predecessors are likely to retain a senior and influential position in the family side of the family-business dyad and substantial firm ownership (Davis \& Harveston). These ties may draw loyalty away from the successor and to the predecessor, thwarting the successor's ability to "formulate, modify, and enact future plans." Thus,

Proposition 4: In a family business, predecessor involvement in the firm attenuates the positive effect of a successor's power base on successor discretion.

\section{Familiness}

The third characteristic of family firms that we argue should be taken into account in discussions of successor discretion is reflected in the notion of "familiness" (Habbershon \& Williams, 1999; Habbershon, Williams, \& Macmillan, 2003). While familiness is most frequently viewed in a positive, constructive light (Rutherford, Kuratko, \& Holt, 2008), some suggest that familiness can be an encumbrance to performance when it is not properly managed (as in the case of familiness-based free-riding problems [Habbershon \& Williams; Sharma, 2008]. In our use of the concept, we focus on the positive, constructive 
side of familiness - often termed distinctive familiness (Habbershon \& Williams; Habbershon et al.) — which involves a more resilient trust and a greater congruence in goals (Habbershon \& Williams; Pearson, Carr, \& Shaw, 2008). In our use of distinctive familiness, we explore the possibility that consequences of familiness stemming from successor discretion exist that are particularly relevant to family firms.

Familiness has been defined as "resources and capabilities related to family involvement and interactions" (Chrisman, Chua, \& Litz, 2003, p. 468). This concept taps into the idea that what makes family firms different from nonfamily firms is the central role that family plays within firms (Pearson et al., 2008). The role of family and the complex interrelationships between family interests, business interests, and individual interests set family firms apart from nonfamily firms and underscores a critically unique dimension of family firms. We argue that familiness, along with the complex family relationships that underlie it, is an important force within family firms that moderates relationships between certain individual-centric attributes of successors and successor discretion. We now discuss two such relationships: political acumen and commitment of successors.

Family Business and Political Acumen. Political acumen represents successors' ability to effectively use the power that they possess, which (as noted) leads to successor discretion (cf. Hambrick \& Finkelstein, 1987). In family firms, however, successors must contend not only with political and power issues common to all firms, but must also contend with complex family relationships and the "familiness" of the firm. As described, familiness represents a unique bundle of resources and capabilities that distinguishes family firms from nonfamily firms (Chua et al., 1999). One important outcome of familiness is that it allows family firms to develop a unique type of social capital that nonfamily firms are unable to develop (Carney, 2005). Social capital is a broad concept that focuses on connections among individuals that facilitate trust, cohesiveness, and the pursuit of uniform goals (Adler \& Kwon, 2002). It taps into the complex relationships within firms and is built over time in intricate and inimitable patterns (Pearson et al., 2008). While all firms can develop social capital, family firms are able to leverage their familiness and develop far more extensive and intricate layers of social capital because of the added complex family relational elements (Arregle, Hitt, Sirmon, \& Very, 2007). This familiness-based social capital thus comprises a unique resource of family firms and can lead to positive outcomes.

We argue that one such positive outcome of familiness-based social capital is that it facilitates successors' use of political acumen as a result of the associated trust and cohesiveness it generates. This is because in situations of greater trust and cohesion, individuals within firms would be more trusting and accepting of the decisions and actions of successors (Miller et al., 2003). In such an environment, it would be easier for successors to exercise their political acumen and make decisions in the best interest of the firm. Thus, we argue that familiness-based social capital is an important positive moderator of the relationship between political acumen and successor discretion. Accordingly,

Proposition 5: In a family business, familiness magnifies the positive effect of a successor's political acumen on successor discretion.

Family Business and Commitment. The effect of familiness on successor discretion is not limited to its positive interaction with political acumen. Commitment of successors has also been identified as an important attribute (e.g., Sharma \& Irving, 2005). But as we have previously noted, too strong a commitment can result in successors being locked into 
a particular course of action, limiting the array of alternatives of which they are aware or to which they give credence, thereby decreasing successor discretion (cf. Hambrick \& Finkelstein, 1987). Our argument is that in family firms, this problem is likely to be compounded.

As previously discussed, familiness in a family firm is built on the complex family, firm, and individual relationships within firms (Pearson et al., 2008) and can be a basis of competitive advantage for family firms (Habbershon \& Williams, 1999). Among its other positive characteristics (e.g., a greater sense of trust and cohesiveness), familiness also provides a "transgenerational pursuance" of vision and purpose for the family firm (Chrisman, Chua, \& Steier, 2005, p. 238). When looked at in terms of successor discretion, this overarching sense of continuity may be seen to encourage successors not to seek new opportunities, but rather to further develop and build upon existing strategies in an effort to further enhance the family firm's familiness. Thus, as a result of the familiness of the firm and out of a desire to further nurture the trust and cohesion that has heretofore preserved the family firm - thereby avoiding conflict (cf. Habbershon \& Williams) successors may actually increase commitment to predecessors' strategies. Paradoxically, then, because of a regenerative focus on renewing distinctive familiness, the familiness of family firms may actually reduce successor discretion. Therefore,

Proposition 6: In a family business, familiness magnifies the negative effect of commitment on successor discretion.

As we have described, there are certain characteristics of family firms and family firm succession that combine to affect successor discretion, some positively and some negatively. As the tension we describe in our introduction suggests, the net effect of these characteristics would seem to imperil the family firm's existence in the very act of trying to facilitate its longevity. Our assertion is that by understanding both successor discretion and the characteristics of family firms that affect it, successors and predecessors can resolve this tension.

\section{Discussion}

In the beginning of Anna Karenina, Leo Tolstoy asserts that "happy families are all alike; every unhappy family is unhappy in its own way." When applied to the context of intergenerational family firms, we disagree with his observation. We do so because it would seem to suggest that while theory can adequately explain successful transitions in the family business from one generation to the next (Sharma et al., 2001, 2003), it is not able to explain those that have failed. It is our belief, however, that the causes of both successful and failed successions can be explained through theory, and as a result may be effected in practice. As we have just reiterated, there is an unhappy reality that the considerable longevity that many family firms enjoy is imperiled by the very processes that are necessary for their continued existence. Our efforts to develop the idea of successor discretion augment family business theory with the aim of improving family business practice. We now address both the theoretical and practical implications of our work.

\section{Theoretical Implications}

We have introduced the construct of successor discretion as an attempt to better understand the "problems of passage" (Miller et al., 2003) that can exist in family firms. As 
a foundation for our development of this construct, we rely upon the concept of managerial discretion (Hambrick \& Finkelstein, 1987) as a basis for us to then explicitly address the human agency element (Bandura, 2001) that we argue exists in successor discretion. With managerial discretion as the basis of our development of successor discretion, we thus acknowledge that successor discretion can apply to all firms, not just family firms. Our line of reasoning, however, is that the concept of successor discretion, as we have defined it, is central to the "problems of passage" that arise in family firm succession. Our propositions develop the logic underlying this expectation and thus build on the growing literature that focuses on succession (e.g., Miller et al.; Sharma et al., 2001).

In addressing problems of passage in family business succession, our theorizing has been focused almost exclusively on understanding those elements of family firms that can magnify problems of passage. However, as our proposition on the interaction between familiness and political acumen exemplifies (proposition 5) factors exist-family firmbased, but also individual-based - that can attenuate problems of passage through the development of successor discretion. We might expect, for instance, that a successor's self-efficacy (e.g., Wood \& Bandura, 1989) or previous involvement in a family firm would increase successor discretion. Additional research is therefore needed to further develop theory that describes how individual-level factors underlying successor discretion can combine with family-level factors to positively affect the strategic behavior of successors. Moreover, further research is needed to understand the implications of the suggestion that distinctive familiness may attenuate successor discretion.

It might be said that the configuration of our proposed model represents a structuralist argument whereby external factors (i.e., characteristics of a family business) constrain and/or limit the effects of individual-level factors on successor discretion. But the picture is not so simple. Our approach to understanding postsuccession success is based on social cognitive theory (see Wood \& Bandura, 1989), which in its most basic sense describes how individual, environmental, and behavioral factors are "interacting determinants that influence each other bidirectionally" (Wood \& Bandura, p. 362, emphasis added). Stated differently, our agency-based approach to postsuccession success (e.g., Bandura, 2001) is based on the idea that: (1) individual-level differences combine with certain family firm-based characteristics to jointly impact successor discretion, and (2) that through successor discretion, successors work to transform the very structure of the family firm itself, thereby changing the nature of its impact on individual-level factors (Giddens, 1979). In this way, our research is squarely centered in a theory of human agency that emphasizes the duality of agency and structure.

In adopting a social cognitive approach to family business succession success, we thus build on a tradition of research that illustrates the importance of individual-level factors for decision makers in both organizations in general (e.g., Miller \& Dröge, 1986) and in family businesses specifically (e.g., Mitchell et al., 2003). By doing so, this paper represents a foundation for future empirical research investigating the role of agency and cognition in family business-based entrepreneurial action. Our paper also represents a step forward in differentiating between entrepreneurial decision makers in the family business context (cf. Sarasvathy, 2004). By understanding the factors that lead to successor discretion, we can better understand the differences in successors' responses to and impact on change in the family business. Moreover, in probing the agency dimension of family business succession, we have identified several ways in which research on successor discretion in family firms can not only constructively advance family business research, but can also enhance understanding of discretion and succession in general.

While we have established successor discretion as a factor that can affect productive change following succession in a family business, nonetheless a number of unanswered 
questions still exist. One important question is the specific nature of the relationship between successor discretion and corporate entrepreneurship in family firms (e.g., Kellermanns \& Eddleston, 2006). Specifically, we argue here that successor discretion affects the level of corporate entrepreneurship in family firms because it allows successors to implement change that is necessary to generate family wealth and thereby enhance the long-term viability of the family firm. What is not clear, however, is how successor discretion might impact the shorter-term survival of family firms. Indeed, greater successor discretion may entail taking greater risks that, while important to the long-term success of the firm (Zahra \& Covin, 1995), nonetheless may endanger the family business in the short run. The complexities of these relationships have yet to be explored.

\section{Practical Implications}

Warren Buffett observed that society has an obligation to ensure that success is based on merit as opposed to inheritance (Thomas, 2006). The enhancement of successor discretion, as we have defined it here, represents a pathway for successors (both family and nonfamily) to achieve merit-based success through the use of agency. Herein, we briefly discuss how decision makers in family firms specifically can achieve such success in practice. We discuss these implications from the perspective of both predecessors and successors.

Herein, we have developed the idea that certain individual characteristics can impact successor discretion. By understanding the factors that can lead to successor discretion and those that can detract from it, predecessors in a family business can proactively work to seek out and develop those characteristics in successors that will lead to increased successor discretion. For instance, predecessors could assist successors in developing political acumen. Because family business characteristics also exist that can impact successor discretion, predecessors should also seek to structure the family firm in a way that enables successor discretion. For instance, this might be done through the institutionalization of a belief that executives are not merely guardians of created wealth, but rather creators of new wealth. In a sense, the development of successor discretion represents a type of succession planning (e.g., Davis \& Harveston, 1998) that begins long before succession.

An underlying premise in our research is the idea that successors must be willing and free to depart from the strategies of predecessors. Predecessors, for their part, enable such discretion by being willing to step aside. We do not want this to be taken, however, as an argument in favor of predecessor disengagement from the family firm. Indeed, such disengagement could be a detriment if relevant experience, expertise, and social capital (among other factors) of predecessors go unused. Instead, we suggest that predecessor involvement in the family firm be targeted in a way that successor discretion is fostered. For instance, predecessors can consistently signal their commitment to successors' courses of action (whatever the actions, large or small) and their willingness to share expertise, but should do so with the understanding that this involvement is subordinate to successor discretion. The key is that successor discretion be understood as having primacy. Moreover, it may be that such an approach on the part of predecessors will both increase successors' satisfaction with the succession process (cf. Sharma et al., 2003) and decrease conflict in the family firm (cf. Davis \& Harveston, 1999).

For their part, successors to a family business can enable successor discretion by taking opportunities to develop those individual characteristics that are positively related to discretion. This might be done through the development of one's own aspirations in the family firm. An irony is that while developing family business aspirations, successors 
should also attempt to develop a view of the business that is independent of its past behavior. By so doing, successors can put themselves in a position to formulate, modify, and enact future plans for the renewal of the company by making critical strategic choices for the firm that are jointly impacted by both their own thinking and the situational factors introduced by the family business. In this way, each generation of leadership in a family business can make a mark: Successor discretion simply ensures these marks entail a new path rather than the retreading of old ground.

\section{REFERENCES}

Adler, P.S. \& Kwon, S.-W. (2002). Social capital: Prospects for a new concept. Academy of Management Review, 27(1), 17-40.

Aldrich, H.E. (1999). Organizations evolving. Thousand Oaks, CA: SAGE Publications.

Arregle, J.-L., Hitt, M.A., Sirmon, D.G., \& Very, P. (2007). The development of organizational social capital: Attributes of family firms. Journal of Management Studies, 44, 73-95.

Bandura, A. (2001). Social cognitive theory: An agentic perspective. Annual Review of Psychology, 52, 1-26.

Baron, R. \& Ensley, M. (2006). Opportunity recognition as the detection of meaningful patterns: Evidence from comparisons of novice and experienced entrepreneurs. Management Science, 52(9), 1331.

Bieri, J., Atkins, A.L., Briar, S., Leaman, R.L., Miller, H., \& Tripodi, T. (1966). Clinical and social judgment: The discrimination of behavioral information. New York: Wiley.

Carney, M. (2005). Corporate governance and competitive advantage in family-controlled firms. Entrepreneurship Theory and Practice, 29(3), 249-265.

Carpenter, M.A. \& Golden, B.R. (1997). Perceived managerial discretion: A study of cause and effect. Strategic Management Journal, 18(3), 187-206.

Chandler, A.D. (1990). Scale and scope: The dynamics of industrial capitalism. Cambridge, MA: Harvard University Press.

Chrisman, J.J., Chua, J.H., \& Litz, R. (2003). A unified systems perspective of family firm performance: An extension and integration. Journal of Business Venturing, 18(4), 467-472.

Chrisman, J.J., Chua, J.H., \& Steier, L. (2005). Sources and consequences of distinctive familiness: An introduction. Entrepreneurship Theory and Practice, 29(3), 237-247.

Chua, J.H., Chrisman, J.J., \& Sharma, P. (1999). Defining the family business by behavior. Entrepreneurship Theory and Practice, 23(4), 19-39.

Cyert, R.M. \& March, J.G. (1963). A behavioral theory of the firm (2nd ed.). Englewood Cliffs, NJ: Prentice-Hall.

Daily, C.M., McDougall, P.P., Covin, J.G., \& Dalton, D.R. (2002). Governance and strategic leadership in entrepreneurial firms. Journal of Management, 28(3), 387-412.

Davis, P.S. \& Harveston, P.D. (1998). The influence of family on family business succession process: A multi-generational perspective. Entrepreneurship Theory and Practice, 22, 31-53.

Davis, P.S. \& Harveston, P.D. (1999). In the founder's shadow: Conflict in the family firm. Family Business Review, 12, 311-323. 
Finkelstein, S. (1992). Power in top management teams: Dimensions, measurement, and validation. Academy of Management Journal, 35(3), 505-538.

Furnham, A. \& Ribchester, T. (1995). Tolerance of ambiguity: A review of the concept, its measurement and applications. Current Psychology, 14(3), 179-199.

Giddens, A. (1979). Central problems in social theory: Action, structure, and contradiction in social analysis. Berkeley: University of California Press.

Guth, W.D. \& Ginsberg, A. (1990). Guest editors' introduction: Corporate entrepreneurship. Strategic Management Journal, 11(5), 5-15.

Górriz, C.G. \& Salas, V. (2006). Survival, behavior and performance of family and non-family firms listed on the Spanish stock exchange. The ICFAI Journal of Corporate Governance, 5(4), 18-42.

Habbershon, T.G. \& Williams, M.L. (1999). A resource-based framework for assessing the strategic advantages of family firms. Family Business Review, 12(1), 1-25.

Habbershon, T.G., Williams, M., \& Macmillan, I.C. (2003). A unified systems perspective of family firm performance. Journal of Business Venturing, 18, 451-465.

Haleblian, J. \& Finkelstein, S. (1993). Top management team size, CEO dominance, and firm performance: The moderating roles of environmental turbulence and discretion. Academy of Management Journal, 36(4), 844-863.

Hambrick, D. \& Finkelstein, S. (1987). Managerial discretion: A bridge between polar views of organizational outcomes. Research in Organizational Behavior, 9, 369-406.

Hambrick, D.C. \& Abrahamson, E. (1995). Assessing managerial discretion across industries: A multimethod approach. Academy of Management Journal, 38(5), 1427-1441.

Handler, W.C. (1992). The succession experience of the next generation. Family Business Review, 5(3), 283-307.

Hannan, M.T. \& Freeman, J. (1984). Structural inertia and organizational change. American Sociological Review, 49, 149-164.

Harriss, J. (2003). The great tradition globalizes: Reflections on two studies of "the industrial leaders" of Madras. Modern Asian Studies, 37(02), 327-362.

Holland, P.G. \& Boulton, W.R. (1984). Balancing the "family" and the "business" in family business. Business Horizons, 27(2), 16.

Ireland, R.D., Hitt, M.A., \& Sirmon, D.G. (2003). A model of strategic entrepreneurship: The construct and its dimensions. Journal of Management, 29(6), 963-989.

Kahneman, D., Knetsch, J., \& Thaler, R. (1990). Experimental tests of the endowment effect and the Coase theorem. Journal of Political Economy, 98(6), 1325.

Kellermanns, F.W. \& Eddleston, K.A. (2006). Corporate entrepreneurship in family firms: A family perspective. Entrepreneurship Theory and Practice, 30(6), 809-830.

Le Breton-Miller, I., Miller, D., \& Steier, L.P. (2004). Toward an integrative model of effective FOB succession. Entrepreneurship Theory and Practice, 28, 305-328.

Leonard-Barton, D. (1992). Core capabilities and core rigidities: A paradox in managing new product development. Strategic Management Journal, 13, 111-125. 
Matthews, C.H., Moore, T.W., \& Fialko, A.S. (1999). Succession in the family firm: A cognitive categorization perspective. Family Business Review, 12, 159-170.

Miller, D. \& Dröge, C. (1986). Psychological and traditional determinants of structure. Administrative Science Quarterly, 31(4), 539-560.

Miller, D., Steier, L., \& Le Breton-Miller, I. (2003). Lost in time: Intergenerational succession, change, and failure in family business. Journal of Business Venturing, 18, 513-531.

Mischel, W. (1977). The interaction of person and situation. In D. Magnusson \& N.S. Endler (Eds.), Personality at the crossroads: Current issues in interactional psychology (pp. 333-352). Hillsdale, NJ: Erlbaum.

Mitchell, R.K., Morse, E.A., \& Sharma, P. (2003). The transacting cognitions of nonfamily employees in the family businesses setting. Journal of Business Venturing, 18(4), 533-551.

Olson, P.D., Zuiker, V.S., Danes, S.M., Stafford, K., Heck, R.K.Z., \& Duncan, K.A. (2003). The impact of the family and the business on family business sustainability. Journal of Business Venturing, 18, 639-666.

Pearson, A.W., Carr, J.C., \& Shaw, J.C. (2008). Toward a theory of familiness: A social capital perspective. Entrepreneurship Theory and Practice, 32(6), 949-969.

Peteraf, M. \& Reed, R. (2007). Managerial discretion and internal alignment under regulatory constraints and change. Strategic Management Journal, 28(11), 1089-1112.

Rotter, J.B. (1990). Internal versus external control of reinforcement: A case history of a variable. American Psychologist, 45(4), 489-493.

Rubenson, G.C. \& Gupta, A.K. (1996). The initial succession: A contingency model of founder tenure. Entrepreneurship Theory and Practice, 21, 21-35.

Rutherford, M.W., Kuratko, D.F., \& Holt, D.T. (2008). Examining the link between "familiness" and performance: Can the F-PEC untangle the family business theory jungle? Entrepreneurship Theory and Practice, 32(6), 1089-1109.

Sarasvathy, S.D. (2004). The questions we ask and the questions we care about: Reformulating some problems in entrepreneurship research. Journal of Business Venturing, 19(5), 707-717.

Schulze, W., Lubatkin, M., Dino, R., \& Buchholtz, A. (2001). Agency relationships in family firms: Theory and evidence. Organization Science, 12(2), 99.

Schumann, D. (1999). Buddenbrooks revisited: The firm and the entrepreneurial family in Germany during the nineteenth and early twentieth centuries. In P.L. Robertson (Ed.), Authority and Control in Modern Industry: Theoretical and Empirical Perspectives (pp. 221-239). London: Routledge.

Searle, J. (2001). Rationality in action. Cambridge, MA: MIT Press.

Sharma, P. (2008). Familiness: Capital stocks and flows between family and business. Entrepreneurship Theory and Practice, 32(6), 971-977.

Sharma, P., Chrisman, J., \& Chua, J. (1997). Strategic management of the family business: Past research and future challenges. Family Business Review, 10(1), 1-35.

Sharma, P., Chrisman, J.J., \& Chua, J.H. (2003). Predictors of satisfaction with the succession process in family firms. Journal of Business Venturing, 18, 667-687.

Sharma, P., Chrisman, J.J., Pablo, A.L., \& Chua, J.H. (2001). Determinants of initial satisfaction with the succession process in family firms: A conceptual model. Entrepreneurship Theory and Practice, 25, $17-35$. 
Sharma, P. \& Irving, P.G. (2005). Four bases of family business successor commitment: Antecedents and consequences. Entrepreneurship Theory and Practice, 29(1), 13-33.

Sharma, P. \& Manikutty, S. (2005). Strategic divestments in family firms: Role of family structure and community culture. Entrepreneurship Theory and Practice, 29(3), 293-311.

Shepherd, D.A. \& Zacharakis, A. (2000). Structuring family business succession: An analysis of the future leader's decision making. Entrepreneurship Theory and Practice, 24, 25-39.

Sirmon, D.G. \& Hitt, M.A. (2003). Managing resources: Linking unique resources, management, and wealth creation in family firms. Entrepreneurship Theory and Practice, 27(4), 339-358.

Smith, K.G. \& Grimm, C.M. (1987). Environmental variation, strategic change and firm performance: A study of railroad deregulation. Strategic Management Journal, 8(4), 363-376.

Staw, B.M., Sandelands, L.E., \& Dutton, J.E. (1981). Threat rigidity effects in organizational behavior: A multilevel analysis. Administrative Science Quarterly, 26(4), 501-524.

Strahilevitz, M.A. \& Loewenstein, G. (1998). The effect of ownership history on the valuation of objects. Journal of Consumer Research, 25(3), 276-289.

Thomas, L.J. (2006, June 27). A gift between friends. New York Times, pp. C1-C4. .

Virany, B., Tushman, M.L., \& Romanelli, E. (1992). Executive succession and organization outcomes in turbulent environments-An organization learning approach. Organization Science, 3(1), 72-91.

Wasserman, N. (2003). Founder-CEO succession and the paradox of entrepreneurial success. Organization Science, 14(2), 149-172.

Weiss, H.M. \& Adler, S. (1984). Personality and organizational behavior. In B.M. Staw \& L.L. Cummings (Eds.), Research in organizational behavior (Vol. 6, pp. 1-50). Greenwich, CT: JAI Press, Inc.

White, M.C., Smith, M., \& Barnett, T. (1994). Strategic inertia: The enduring impact of CEO specialization and strategy on following strategies. Journal of Business Research, 31(1), 11-22.

Woike, B.A. \& Aronoff, J. (1992). Antecedents of complex social cognitions. Journal of Personality and Social Psychology, 63(1), 97-104.

Wong, S.-L. (1985). The Chinese family firm: A model. The British Journal of Sociology, 36(1), 58-72.

Wood, R. \& Bandura, A. (1989). Social cognitive theory of organizational management. Academy of Management Review, 14(3), 361-384.

Zahra, S.A. \& Covin, J.G. (1995). Contextual influences on the corporate entrepreneurship-performance relationship: A longitudinal analysis. Journal of Business Venturing, 10(1), 43.

Post-print standardized by MSL Academic Endeavors, the imprint of the Michael Schwartz Library at Cleveland State University, 2016 